\title{
Meta-Analysis of Effect in Serum Bio-Markers for Early Diagnosis: Rheumatoid Arthritis
}

\author{
Myoung Soo Woo ${ }^{1, *}$, Sora Mun ${ }^{2, * *}$ and Hee-Gyoo Kang ${ }^{2, ;, *}$ \\ ${ }^{I}$ Department of Biomedical Laboratory Science, Jeonju Kijeon College, Jeonju 54989, Korea \\ ${ }^{2}$ Department of Biomedical Laboratory Science, College of Health Sciences, \\ Eulji University, Seongnam 13135, Korea
}

\begin{abstract}
Rheumatoid arthritis refers to acute and chronic arthritis due to unexplained autoantibody attack. Rheumatoid arthritis should be accompanied by difficulty in mobility and severe distress due to the progression of systemic arthritis. Therefore, this study early diagnoses the effects of Rheumatoid factor (RF), C-reactive protein (CRP), and Anti-cyclic citrullinated peptide (Anti-CCP), which are typical serum markers for rheumatoid arthritis by meta-analysis. Pubmed and EMBASE, were used as PICO criteria, and two independent researchers selected papers according to the criteria set in this study. The selection criteria was a study of patients with rheumatoid arthritis who developed early onset, and the paper was evaluated using the NCS. Forest plot and Funnel plot graphs for each serum marker were calculated using Revman 5.4. After finding 193 papers on Pubmed and 184 papers on EMBASE and selecting according to the criteria, a total of 41 papers were used for the analysis. The magnitude of the effect that appears in the Forest plot of RF with the Mean differnce value is $134.34, \mathrm{CRP}$ is 21.42 and Anti-CCP is 270.41. The magnitude of the effect of Anti-CCP in meta-analysis was analyzed to be larger than that of RF and CRP, and it is considered that the development of early-diagnosis serum markers using Anti-CCP and additional retrospective studies are highly effective. The combination of RF, CRP, and Anti-CCP as a panel marker is expected to be very efficient.
\end{abstract}

Key Words: Arthritis, Rheumatoid; Rheumatoid factor; C-reactive protein; Anti-CCP

\section{서 론}

류마티스 관절염은 원인 불분명의 자가항체 공격으로 인한 급성 및 만성 관절염을 의미하며, 관절염에 의한 이 동성 어려움과 통증 수반으로 인해 삶의 질이 저하된다 (Mun et al., 2018). 또한, 관절 염증의 진행으로 인해 전신 관절염으로 진행되어 극심한 고통이 수반된다. 따라서, 현재까지 효과적인 치료방법이 존재하지 않아 기타 만성 질환과 같이 조기 진단 및 관리를 통한 질환 진행을 최
소화 하여야 한다(Lee and Lee, 2020).

류마티스 관절염 진단에 사용되는 대표적인 혈청 마커 의 종류는 RF, CRP, Anti-CCP이다(Mun et al., 2021). RF는 류마티스 관절염 환자 혈청에서 대조군에 비해 증가되며, 대부분 류마티스 관절염 연구에서 대조군으로 보통 사용 된다(Shen et al., 2015). 그러나, 류마티스 관절염 환자가 아님에도 RF가 증가하는 경우도 있다(Nell et al., 2005). $\mathrm{CRP}$ 는 대체로 단독으로 사용되기 보다는 CRP level 값과 영상 진단 결과를 조합한 Disease Activity Score 28-CRP (DAS28-CRP) 기준이 사용된다(Aletaha et al., 2010). 그러나,

Received: November 16, 2021 / Revised: December 12, 2021 / Accepted: December 13, 2021

*Professor, ${ }^{* *}$ Researcher fellow.

${ }^{\dagger}$ Corresponding author: Hee-Gyoo Kang. Department of Biomedical Laboratory Science, College of Health Sciences, Eulji University, Seongnam 13135, Korea.

Tel: +82-31-740-7303, Fax: +82-31-740-7303, e-mail: kanghg@eulji.ac.kr

(C) The Korean Society for Biomedical Laboratory Sciences. All rights reserved.

(c) This is an Open Access article distributed under the terms of the Creative Commons Attribution Non-Commercial License (http://creativecommons.org/licenses/by-nc/3.0/) which permits unrestricted non-commercial use, distribution, and reproduction in any medium, provided the original work is properly cited. 
Table 1. Quality assessment by NOS (New castle-Ottawa Score) for included studies

\begin{tabular}{|c|c|c|c|c|c|c|c|c|}
\hline \multirow[b]{2}{*}{ Study } & \multicolumn{4}{|c|}{ Selection } & \multirow{2}{*}{$\begin{array}{c}\text { Comparability } \\
\text { Comparability of cases } \\
\text { and controls on the } \\
\text { basis of the design } \\
\text { or analysis }\end{array}$} & \multicolumn{3}{|c|}{ Exposure } \\
\hline & $\begin{array}{l}\text { Is the case } \\
\text { definition } \\
\text { adequate }\end{array}$ & $\begin{array}{l}\text { Represen- } \\
\text { tativeness of } \\
\text { the cases }\end{array}$ & $\begin{array}{l}\text { Selection } \\
\text { of controls }\end{array}$ & $\begin{array}{l}\text { Definition } \\
\text { of controls }\end{array}$ & & $\begin{array}{l}\text { Ascertainment } \\
\text { of exposure }\end{array}$ & $\begin{array}{l}\text { Same method } \\
\text { of ascertainment } \\
\text { for case and } \\
\text { controls }\end{array}$ & $\begin{array}{l}\text { Non- } \\
\text { Response } \\
\text { rate }\end{array}$ \\
\hline Ahlin 2015 & $*$ & $*$ & & $*$ & $* *$ & * & $*$ & \\
\hline Aiman 2020 & $*$ & $*$ & & & $* *$ & $*$ & $*$ & \\
\hline Anaparti 2019 & $*$ & $*$ & & $*$ & $* *$ & $*$ & $*$ & \\
\hline Shazly 2014 & $*$ & $*$ & & $*$ & $*$ & * & $*$ & \\
\hline El-Banna 2014 & $*$ & $*$ & & $*$ & $* *$ & $*$ & $*$ & \\
\hline Guo 2015 & $*$ & $*$ & & & $* *$ & $*$ & $*$ & \\
\hline Hasemi 2018 & $*$ & $*$ & & $*$ & $* *$ & $*$ & $*$ & \\
\hline Henandez 2017 & $*$ & $*$ & & $*$ & $* *$ & $*$ & $*$ & \\
\hline Iranshahi 2019 & $*$ & $*$ & & $*$ & $* *$ & $*$ & $*$ & \\
\hline Janssen 2015 & $*$ & $*$ & & $*$ & $* *$ & $*$ & $*$ & \\
\hline Konda 2017 & $*$ & $*$ & & $*$ & $* *$ & $*$ & $*$ & \\
\hline Liao 2011 & $*$ & $*$ & & & $*$ & $*$ & $*$ & \\
\hline Meyer 2018 & $*$ & $*$ & & $*$ & $* *$ & $*$ & $*$ & \\
\hline Nass 2017 & $*$ & $*$ & $*$ & $*$ & $* *$ & $*$ & $*$ & \\
\hline Okada 2011 & $*$ & $*$ & & $*$ & $* *$ & * & $*$ & \\
\hline $\begin{array}{l}\text { Reyes-perez } \\
2019\end{array}$ & $*$ & $*$ & $*$ & $*$ & $* *$ & $*$ & $*$ & \\
\hline Shakiba 2014 & $*$ & $*$ & & $*$ & $* *$ & $*$ & $*$ & $*$ \\
\hline Wei 2020 & $*$ & $*$ & & $*$ & $* *$ & $*$ & $*$ & \\
\hline Zeng 2020 & $*$ & $*$ & & $*$ & $* *$ & * & $*$ & \\
\hline $\begin{array}{l}\text { Abdul makoud } \\
2017\end{array}$ & $*$ & $*$ & & * & $* *$ & * & $*$ & \\
\hline Anaparti 2021 & $*$ & $*$ & $*$ & $*$ & $* *$ & $*$ & $*$ & \\
\hline Aslanalp 2020 & $*$ & $*$ & & $*$ & $* *$ & $*$ & $*$ & \\
\hline Cao 2019 & $*$ & * & & $*$ & $* *$ & * & $*$ & \\
\hline Giles 2015 & $*$ & $*$ & & & $* *$ & $*$ & $*$ & \\
\hline Guan 2019 & $*$ & $*$ & & $*$ & $* *$ & $*$ & $*$ & \\
\hline $\begin{array}{l}\text { HADINEDOUSHAN } \\
2016\end{array}$ & $*$ & $*$ & $*$ & $*$ & $* *$ & $*$ & $*$ & \\
\hline Hussein 2021 & $*$ & $*$ & & $*$ & $* *$ & $*$ & $*$ & \\
\hline Kahn 2012 & $*$ & $*$ & & $*$ & $* *$ & $*$ & $*$ & \\
\hline Mohan 2017 & $*$ & $*$ & & $*$ & $* *$ & $*$ & $*$ & \\
\hline Lazm 2018 & $*$ & & & & $* *$ & $*$ & $*$ & \\
\hline Li 2019 & $*$ & $*$ & & $*$ & $* *$ & $*$ & $*$ & \\
\hline $\begin{array}{l}\text { Maksymowych } \\
2014\end{array}$ & $*$ & $*$ & & $*$ & $* *$ & $*$ & $*$ & \\
\hline Mohamed 2019 & $*$ & $*$ & & $*$ & $* *$ & $*$ & $*$ & \\
\hline Narayan 2019 & * & $*$ & & * & $* *$ & $*$ & $*$ & \\
\hline Ozkan 2012 & $*$ & * & & $*$ & $* *$ & $*$ & $* *$ & \\
\hline $\begin{array}{l}\text { Ramwadhdoebe } \\
2019\end{array}$ & $*$ & $*$ & & $*$ & $* *$ & $*$ & $*$ & \\
\hline
\end{tabular}


Table 1. Quality assessment by NOS (New castle-Ottawa Score) for included studies (Continued)

\begin{tabular}{|c|c|c|c|c|c|c|c|c|}
\hline \multirow[b]{2}{*}{ Study } & \multicolumn{4}{|c|}{ Selection } & \multirow{2}{*}{$\begin{array}{c}\text { Comparability } \\
\text { Comparability of cases } \\
\text { and controls on the } \\
\text { basis of the design } \\
\text { or analysis }\end{array}$} & \multicolumn{3}{|c|}{ Exposure } \\
\hline & $\begin{array}{l}\text { Is the case } \\
\text { definition } \\
\text { adequate }\end{array}$ & $\begin{array}{l}\text { Represen- } \\
\text { tativeness of } \\
\text { the cases }\end{array}$ & $\begin{array}{l}\text { Selection } \\
\text { of controls }\end{array}$ & $\begin{array}{l}\text { Definition } \\
\text { of controls }\end{array}$ & & $\begin{array}{l}\text { Ascertainment } \\
\text { of exposure }\end{array}$ & $\begin{array}{l}\text { Same method } \\
\text { of ascertainment } \\
\text { for case and } \\
\text { controls }\end{array}$ & $\begin{array}{l}\text { Non- } \\
\text { Response } \\
\text { rate }\end{array}$ \\
\hline Rykova 2017 & * & $*$ & & $*$ & $* *$ & $*$ & $*$ & \\
\hline Shen 2014 & $*$ & $*$ & & $*$ & $* *$ & * & $*$ & \\
\hline Shrivastava 2015 & $*$ & $*$ & & $*$ & $* *$ & $*$ & $*$ & \\
\hline Tuncer 2019 & $*$ & * & & $*$ & $* *$ & $*$ & $*$ & \\
\hline Yan 2019 & $*$ & $*$ & & & $* *$ & $*$ & $*$ & \\
\hline Yang 2015 & $*$ & $*$ & & $*$ & $* *$ & $*$ & $*$ & \\
\hline
\end{tabular}

CRP도 다른 염증 질환에서도 증가하므로 류마티스 관절 염의 진단 특이도는 매우 떨어진다(Otterness, 1994). Anti$\mathrm{CCP}$ 는 시트룰린화된 단백질에 대한 자가항체를 의미 하며, 가장 민감도와 특이도가 높은 것으로 알려져 있다 (Mimori, 2005).

이번 논문의 목적은 실제 출판되어 조기 진단된 류마 티스 관절염의 RF, $\mathrm{CRP}$, Anti-CCP의 연구 데이타를 바탕 으로 하여 각 혈청 마커들의 효과를 비교 분석하고, 메타 분석 결과를 토대로 하여 향후 조합 마커의 중요성과 좀 더 다양하고 세밀한 대상자 특성에 부합한 질환 마커의 후향적 연구의 필요성을 제시하고자 한다.

\section{재료 및 방법}

\section{문헌 검색법 및 문헌 스크리닝 기준}

문헌 수집과 전체 과정은 Preferred Reporting Items for Systematic Reviews and Meta-Analysis (PRISMA)에서 제 시한 체계적 문헌고찰 보고지침에 근거하여 실시하였다 (Page et al., 2021). 본 연구에서는 PICO 양식(Participants, Intervention, Comparisons, Outcomes)을 이용한 연구 주제 를 설정하였다. 우선 실험군(Participants)을 조발성 류마티 스 관절염 진단을 받은 성인이다. 중재와 비교중재(Intervention, Comparisons)는 본 연구와 관련이 없어 설정하지 않았다. 결과(Outcomes)는 류마티스 관절염군과 대조군의 혈청 마커량이다.

본 연구에서 학술 DB 검색은 Pubmed와 EMBASE를 기 준으로 문헌 검색을 하였다. 2 개의 $\mathrm{DB}$ 모두 영어로 된 문 헌으로 제한하였으며 검색 기간은 2011년 1월부터 2021년 5월 21일 까지로 하였다. Anti-CCP Pubmed 검색식은
"Rheumatoid arthritis" AND "rheumatoid factor" AND "anti$\mathrm{CCP} " \mathrm{AND}$ "ELISA" 그리고 옵션에서 'human'을 선택하 였고, EMBASE 검색식은('rheumatoid arthritis'/exp OR 'rheumatoid arthritis') AND ('rheumatoid factor'/exp OR 'rheumatoid factor') AND 'anti-ccp' AND ('elisa/exp' OR 'elisa') 그리고 옵 션에서는 'human'과 'article'을 선택하였다. CRP Pubmed 검색식은 "Rheumatoid arthritis" AND "rheumatoid factor" AND "C-reactive protein" AND "ELISA" 그리고 옵션에서 'human'을 선택하였고, EMBASE 검색식은('rheumatoid arthritis'/exp OR 'rheumatoid arthritis') AND ('rheumatoid factor' /exp OR 'rheumatoid factor') AND ('c-reactive protein/exp' OR 'c-reactive protein') AND ('elisa/exp' OR 'elisa') 그리고 옵션 에서는 'human'과 'article'을 선택하였다. 검색된 문헌은 서 지 프로그램(Endnote 20)을 이용하여 중복된 문헌을 제거 하였고, 1 차로 제목과 초록을 통하여 '류마티스 관절염'과 '혈청 마커'의 키워드가 포함된 논문을 스크리닝 한다. 2 차 로 full text 논문이 없는 것은 제외하고 full text 논문이라 도 ELISA 결과로 나타내지 않는 논문은 모두 제외하였다. 이 방법은 2 명의 독립적인 리뷰어 역할로 하여 합의 진 행하였다.

\section{문헌 질평가}

New castle Ottawa Score (NOS)-Case Control protocol을 기 준으로 하여 2 명의 연구자에 의해 독립적인 논문 평가를 시행하였다(Table 1). Selction은 case 선택의 기준이 독립적 또는 대표성을 갖는지와 Control의 선정 및 정의가 정확 한지에 대한 평가이다. 이 분야에서 최대 4 개 별점을 얻 을 수 있다. Comparability는 Control 대비 실험 테스트의 수를 의미한다. 최대 2개 별점을 얻을 수 있다. Exposure 
Table 2. Characteristics of study data included in the meta-analysis

\begin{tabular}{|c|c|c|c|c|c|c|c|}
\hline Study & Sample & Test & $\begin{array}{l}\text { Control } \\
\text { (n) }\end{array}$ & $\begin{array}{l}\mathrm{RA}^{* * *} \\
\text { (n) }\end{array}$ & $\begin{array}{l}\text { Anti-CCP } \\
\left(\mathrm{SD}^{*}\right)\end{array}$ & $\begin{array}{l}\mathrm{RF}^{\pi \pi} \\
(\mathrm{SD})\end{array}$ & $\begin{array}{l}\mathrm{CRP}^{\operatorname{m+T}} \\
\text { (SD) }\end{array}$ \\
\hline $\begin{array}{l}\text { Ahlin } 2015 \\
\text { (Åhlin et al., 2015) }\end{array}$ & Serum & ELISA $^{\dagger}$ & 93 & 19 & $\begin{array}{l}\text { Con }^{* *}: 51 \mathrm{U} / \mathrm{mL} \\
\text { RA: } 1,265 \mathrm{U} / \mathrm{mL}\end{array}$ & $\begin{array}{l}\text { Con: } 20 \mathrm{IU} / \mathrm{mL} \\
\text { RA: } 239 \mathrm{IU} / \mathrm{mL}\end{array}$ & \\
\hline $\begin{array}{l}\text { Aiman } 2020 \\
\text { (Aiman et al., 2020) }\end{array}$ & Serum & ELISA & 78 & 135 & $\begin{array}{l}\text { Con: } 2.64(0.49) \mathrm{IU} / \mathrm{mL} \\
\text { RA: } 31.34(5.63) \mathrm{IU} / \mathrm{mL}\end{array}$ & $\begin{array}{l}\text { Con: } 25.36(3.12) \mathrm{IU} / \mathrm{mL} \\
\text { RA: } 116.79(16.23) \mathrm{IU} / \mathrm{mL}\end{array}$ & \\
\hline $\begin{array}{l}\text { Anaparti } 2019 \\
\text { (Anaparti et al., 2019) }\end{array}$ & Serum & ELISA & 77 & 56 & $\begin{array}{l}\text { Con: } 42.6(86.72) \mathrm{U} / \mathrm{mL} \\
\text { RA: } 169.1(109) \mathrm{U} / \mathrm{mL}\end{array}$ & $\begin{array}{l}\text { Con: } 61.5(221.16) \mathrm{IU} / \mathrm{mL} \\
\text { RA: } 563.6(806) \mathrm{IU} / \mathrm{mL}\end{array}$ & $\begin{array}{l}\text { FDR: } 4.8(4.51) \mathrm{mg} / \mathrm{L} \\
\text { RA: } 10.82(15.2) \mathrm{mg} / \mathrm{L}\end{array}$ \\
\hline $\begin{array}{l}\text { Shazly } 2014 \\
\text { (El Shazly et al., 2014) }\end{array}$ & Serum & ELISA & 30 & 50 & $\begin{array}{l}\text { Con: } 1.72(1.104) \mathrm{U} / \mathrm{mL} \\
\text { RA: } 252.63(284.51) \mathrm{U} / \mathrm{mL}\end{array}$ & & \\
\hline $\begin{array}{l}\text { El-Banna } 2014 \\
\text { (El-Banna and } \\
\text { Jiman-Fatani, 2014) }\end{array}$ & Serum & ELISA & 90 & 120 & $\begin{array}{l}\text { Con: } 4.41(1.20) \mathrm{IU} / \mathrm{mL} \\
\text { RA: } 62.54(21.22) \mathrm{IU} / \mathrm{mL}\end{array}$ & $\begin{array}{l}\text { Con: } 13.5 \text { (21) IU/mL } \\
\text { RA: } 149.34 \text { (64.30) IU/mL }\end{array}$ & \\
\hline $\begin{array}{l}\text { Guo } 2015 \\
\text { (Guo et al., 2015) }\end{array}$ & Serum & ELISA & 10 & 23 & $\begin{array}{l}\text { Con: } 4 \text { (2) U/mL } \\
\text { RA: } 200(15) \mathrm{U} / \mathrm{mL}\end{array}$ & $\begin{array}{l}\text { Con: } 15(10) \mathrm{IU} / \mathrm{mL} \\
\text { RA: } 135(10) \mathrm{IU} / \mathrm{mL}\end{array}$ & \\
\hline $\begin{array}{l}\text { Hasemi } 2018 \\
\text { (Hashemi et al., 2018) }\end{array}$ & Serum & ELISA & 240 & 240 & $\begin{array}{l}\text { Con: } 1.82(0.97) \mathrm{U} / \mathrm{mL} \\
\text { RA: } 72.05(19.44) \mathrm{U} / \mathrm{mL}\end{array}$ & & \\
\hline $\begin{array}{l}\text { Hernandez } 2017 \\
\text { (Hernández-Bello } \\
\text { et al., 2017) }\end{array}$ & Serum & ELISA & 240 & 240 & $\begin{array}{l}\text { Con: } 1.52 \mathrm{U} / \mathrm{mL} \\
\text { RA: } 57.5 \mathrm{U} / \mathrm{mL}\end{array}$ & $\begin{array}{l}\text { Con: } 14 \mathrm{UI} / \mathrm{mL} \\
\text { RA: } 129 \mathrm{UI} / \mathrm{mL}\end{array}$ & \\
\hline $\begin{array}{l}\text { Iranshahi } 2019 \\
\text { (Iranshahi et al., } \\
\text { 2019) }\end{array}$ & Serum & ELISA & 42 & 47 & $\begin{array}{l}\text { Con: } 5.074(24.53) \mathrm{U} / \mathrm{mL} \\
\text { RA: } 82.687(85.641) \mathrm{U} / \mathrm{mL}\end{array}$ & $\begin{array}{l}\text { Con: } 0 \mathrm{UI} / \mathrm{mL} \\
\text { RA: } 1 \mathrm{UI} / \mathrm{mL}\end{array}$ & \\
\hline $\begin{array}{l}\text { Janssen } 2015 \\
\text { (Janssen et al., 2015) }\end{array}$ & Serum & ELISA & 36 & 86 & $\begin{array}{l}\text { Con: } 2 \mathrm{U} / \mathrm{mL} \\
\text { RA: } 1,000 \mathrm{U} / \mathrm{mL}\end{array}$ & $\begin{array}{l}\text { Con: } 2 \mathrm{IU} / \mathrm{mL} \\
\text { RA: } 500 \mathrm{IU} / \mathrm{mL}\end{array}$ & $\begin{array}{l}\text { Con: } 0.4 \mathrm{mg} / \mathrm{L} \\
\text { RA: } 1.9 \mathrm{mg} / \mathrm{L}\end{array}$ \\
\hline $\begin{array}{l}\text { Konda } 2017 \\
\text { (Konda Mohan } \\
\text { et al., 2017) }\end{array}$ & Serum & ELISA & 200 & 200 & $\begin{array}{l}\text { Con: } 2.83(5.58) \mathrm{U} / \mathrm{mL} \\
\text { RA: } 68.2(100.85) \mathrm{U} / \mathrm{mL}\end{array}$ & $\begin{array}{l}\text { Con: } 25.98 \text { (40.67) U/mL } \\
\text { RA: } 205.66(234.11) \mathrm{U} / \mathrm{mL}\end{array}$ & \\
\hline $\begin{array}{l}\text { Liao } 2011 \\
\text { (Liao et al., 2011) }\end{array}$ & Serum & ELISA & 24 & 95 & $\begin{array}{l}\text { Con: } 12.7(2.7) \mathrm{U} / \mathrm{mL} \\
\text { RA: } 2185(4533.9) \mathrm{U} / \mathrm{mL}\end{array}$ & & \\
\hline $\begin{array}{l}\text { Meyer } 2018 \\
\text { (Meyer et al., 2018) }\end{array}$ & Serum & ELISA & 29 & 75 & $\begin{array}{l}\text { Con: } 6 \mathrm{U} / \mathrm{mL} \\
\text { RA: } 494 \mathrm{U} / \mathrm{mL}\end{array}$ & & \\
\hline $\begin{array}{l}\text { Nass } 2017 \\
\text { (Nass et al., 2017) }\end{array}$ & Serum & ELISA & 92 & 210 & $\begin{array}{l}\text { Con: } 10 \mathrm{U} / \mathrm{mL} \\
\text { RA: } 160 \mathrm{U} / \mathrm{mL}\end{array}$ & $\begin{array}{l}\text { Con: } 5 \mathrm{U} / \mathrm{mL} \\
\text { RA: } 10 \mathrm{U} / \mathrm{mL}\end{array}$ & \\
\hline $\begin{array}{l}\text { Okada } 2011 \\
\text { (Okada et al., 2011) }\end{array}$ & Serum & ELISA & 38 & 80 & $\begin{array}{l}\text { Con: } 0.6 \mathrm{U} / \mathrm{mL} \\
\text { RA: } 250 \mathrm{U} / \mathrm{mL}\end{array}$ & RA: $148.6(29.4) \mathrm{IU} / \mathrm{mL}$ & \\
\hline $\begin{array}{l}\text { Reyes-perez } 2019 \\
\text { (Reyes-Pérez et al., } \\
\text { 2019) }\end{array}$ & Serum & ELISA & 80 & 20 & $\begin{array}{l}\text { Con: } 0.4 \mathrm{U} / \mathrm{mL} \\
\text { RA: } 149.1 \mathrm{U} / \mathrm{mL}\end{array}$ & $\begin{array}{l}\text { Con: } 5.7 \mathrm{U} / \mathrm{mL} \\
\text { RA: } 90.2 \mathrm{U} / \mathrm{mL}\end{array}$ & \\
\hline $\begin{array}{l}\text { Shakiba } 2014 \\
\text { (Shakiba et al., 2014) }\end{array}$ & Serum & ELISA & 399 & 418 & & $\begin{array}{l}\text { Con: } 18.5 \mathrm{U} / \mathrm{mL} \\
\text { RA: } 68.9 \mathrm{U} / \mathrm{mL}\end{array}$ & \\
\hline $\begin{array}{l}\text { Wei } 2020 \\
\text { (Wei et al., 2020) }\end{array}$ & Serum & ELISA & 45 & 41 & & $\begin{array}{l}\text { Con: } 16.2(10.9) \mathrm{IU} / \mathrm{mL} \\
\text { RA: } 580.2(950.2) \mathrm{IU} / \mathrm{mL}\end{array}$ & $\begin{array}{l}\text { Con: } 4.9(3.8) \mathrm{mg} / \mathrm{L} \\
\text { RA: } 57.5(61.2) \mathrm{mg} / \mathrm{L}\end{array}$ \\
\hline $\begin{array}{l}\text { Zeng } 2020 \\
\text { (Zeng et al., 2020) }\end{array}$ & Serum & ELISA & 77 & 113 & $\begin{array}{l}\text { Con: } 17.78 \mathrm{U} / \mathrm{mL} \\
\text { RA: } 104.53 \mathrm{U} / \mathrm{mL}\end{array}$ & $\begin{array}{l}\text { Con: } 13.63 \mathrm{U} / \mathrm{mL} \\
\text { RA: } 91.51 \mathrm{U} / \mathrm{mL}\end{array}$ & \\
\hline $\begin{array}{l}\text { Abdul maksoud } 2017 \\
\text { (Abdul-Maksoud } \\
\text { et al., 2017) }\end{array}$ & Serum & ELISA & 100 & 100 & $\begin{array}{l}\text { Con: } 10 \mathrm{U} / \mathrm{mL} \\
\text { RA: } 120 \mathrm{U} / \mathrm{mL}\end{array}$ & $\begin{array}{l}\text { Con: } 23 \mathrm{IU} / \mathrm{mL} \\
\text { RA: } 150 \mathrm{IU} / \mathrm{mL}\end{array}$ & $\begin{array}{l}\text { Con: } 10 \mathrm{mg} / \mathrm{L} \\
\text { RA: } 34 \mathrm{mg} / \mathrm{L}\end{array}$ \\
\hline $\begin{array}{l}\text { Anaparti } 2021 \\
\text { (Anaparti et al., 2021) }\end{array}$ & Serum & ELISA & 64 & 50 & $\begin{array}{l}\text { Con: } 63.52(94.79) \mathrm{U} / \mathrm{mL} \\
\text { RA: } 222.4(107.6) \mathrm{U} / \mathrm{mL}\end{array}$ & $\begin{array}{l}\text { Con: } 58.83(240.8) \mathrm{IU} / \mathrm{mL} \\
\text { RA: } 472.6(770.2) \mathrm{IU} / \mathrm{mL}\end{array}$ & $\begin{array}{l}\text { Con: } 6.23(7.28) \mathrm{mg} / \mathrm{L} \\
\text { RA: } 13.28(16.4) \mathrm{mg} / \mathrm{L}\end{array}$ \\
\hline
\end{tabular}


Table 2. Characteristics of study data included in the meta-analysis (Continued)

\begin{tabular}{|c|c|c|c|c|c|c|c|}
\hline Study & Sample & Test & $\begin{array}{c}\text { Control } \\
\text { (n) }\end{array}$ & $\begin{array}{c}\mathrm{RA}^{* * *} \\
(\mathrm{n})\end{array}$ & $\begin{array}{l}\text { Anti-CCP } \\
\left(\mathrm{SD}^{*}\right)\end{array}$ & $\begin{array}{l}\mathrm{RF}^{\prime \pi} \\
(\mathrm{SD})\end{array}$ & $\begin{array}{l}\text { CRP } \\
\text { (SD) }\end{array}$ \\
\hline $\begin{array}{l}\text { Aslanalp } 2020 \\
\text { (Aslanalp et al., 2020) }\end{array}$ & Serum & ELISA & 20 & 40 & $\begin{array}{l}\text { Con: } 20.0(0) \mathrm{U} / \mathrm{mL} \\
\text { RA: } 249.8(208.8) \mathrm{U} / \mathrm{mL}\end{array}$ & $\begin{array}{l}\text { Con: } 9.0(0) \mathrm{IU} / \mathrm{mL} \\
\text { RA: } 136.2(203.9) \mathrm{IU} / \mathrm{mL}\end{array}$ & $\begin{array}{l}\text { Con: } 2.2(0.5) \mathrm{mg} / \mathrm{L} \\
\text { RA: } 7.6(6.7) \mathrm{mg} / \mathrm{L}\end{array}$ \\
\hline $\begin{array}{l}\text { Cao } 2019 \\
\text { (Cao et al., 2019) }\end{array}$ & Serum & ELISA & 30 & 30 & & $\begin{array}{l}\text { Con: } 10.4 \mathrm{IU} / \mathrm{mL} \\
\text { RA: } 92.6 \mathrm{IU} / \mathrm{mL}\end{array}$ & $\begin{array}{l}\text { Con: } 3.1 \mathrm{mg} / \mathrm{L} \\
\text { RA: } 20.43 \mathrm{mg} / \mathrm{L}\end{array}$ \\
\hline $\begin{array}{l}\text { Giles } 2015 \\
\text { (Giles et al., 2015) }\end{array}$ & Serum & ELISA & 198 & 195 & & & $\begin{array}{l}\text { Con: } 2.3 \mathrm{mg} / \mathrm{L} \\
\text { RA: } 2.5 \mathrm{mg} / \mathrm{L}\end{array}$ \\
\hline $\begin{array}{l}\text { Guan } 2019 \\
\text { (Guan et al., 2019) }\end{array}$ & Serum & ELISA & 40 & 94 & $\begin{array}{l}\text { Con: } 3.0 \mathrm{U} / \mathrm{mL} \\
\text { RA: } 395.7 \mathrm{U} / \mathrm{mL}\end{array}$ & $\begin{array}{l}\text { Con: } 20.0 \mathrm{IU} / \mathrm{mL} \\
\text { RA: } 140.5 \mathrm{IU} / \mathrm{mL}\end{array}$ & \\
\hline $\begin{array}{l}\text { HADINEDOUSHAN } \\
2016 \text { (Hadinedoushan } \\
\text { et al., 2016) }\end{array}$ & Serum & ELISA & 90 & 90 & & $\begin{array}{l}\text { Con: } 9.11(2.33) \mathrm{IU} / \mathrm{mL} \\
\text { RA: } 15.42(8.69) \mathrm{IU} / \mathrm{mL}\end{array}$ & \\
\hline $\begin{array}{l}\text { Hussein } 2021 \\
\text { (Hussein et al., 2021) }\end{array}$ & Serum & ELISA & 50 & 50 & $\begin{array}{l}\text { Con: } 10(4.4) \mathrm{U} / \mathrm{mL} \\
\text { RA: } 187.25(165.98) \mathrm{U} / \mathrm{mL}\end{array}$ & $\begin{array}{l}\text { Con: } 6(1.4) \mathrm{IU} / \mathrm{mL} \\
\text { RA: } 150.63(128.61) \mathrm{IU} / \mathrm{mL}\end{array}$ & \\
\hline $\begin{array}{l}\text { Kahn } 2012 \\
\text { (Khan et al., 2012) }\end{array}$ & Serum & ELISA & 25 & 24 & & & $\begin{array}{l}\text { Con: } 4 \mathrm{mg} / \mathrm{L} \\
\text { RA: } 63 \mathrm{mg} / \mathrm{L}\end{array}$ \\
\hline $\begin{array}{l}\text { Mohan } 2017 \\
\text { (Konda Mohan } \\
\text { et al., 2017) }\end{array}$ & Serum & ELISA & 200 & 200 & $\begin{array}{l}\text { Con: } 2.83(5.58) \mathrm{U} / \mathrm{mL} \\
\text { RA: } 68.02(100.85) \mathrm{U} / \mathrm{mL}\end{array}$ & $\begin{array}{l}\text { Con: } 25.98 \text { (40.67) U/mL } \\
\text { RA: } 205.66(234.11) \mathrm{U} / \mathrm{mL}\end{array}$ & \\
\hline $\begin{array}{l}\text { Lazm } 2018 \\
\text { (Lazm et al., 2018) }\end{array}$ & Serum & ELISA & 50 & 50 & & $\begin{array}{l}\text { Con: } 5.26(0.42) \mathrm{IU} / \mathrm{mL} \\
\text { RA: } 65.75(5.71) \mathrm{IU} / \mathrm{mL}\end{array}$ & $\begin{array}{l}\text { Con: } 4.42(0.23) \mathrm{mg} / \mathrm{L} \\
\text { RA: } 32.29(3.60) \mathrm{mg} / \mathrm{L}\end{array}$ \\
\hline $\begin{array}{l}\text { Li } 2019 \\
\text { (Li et al., 2019) }\end{array}$ & Serum & ELISA & 50 & 163 & $\begin{array}{l}\text { Con: } 10 \mathrm{U} / \mathrm{mL} \\
\text { RA: } 130 \mathrm{U} / \mathrm{mL}\end{array}$ & $\begin{array}{l}\text { Con: } 10 \mathrm{IU} / \mathrm{mL} \\
\text { RA: } 420 \mathrm{IU} / \mathrm{mL}\end{array}$ & $\begin{array}{l}\text { Con: } 14 \mathrm{mg} / \mathrm{L} \\
\text { RA: } 30 \mathrm{mg} / \mathrm{L}\end{array}$ \\
\hline $\begin{array}{l}\text { Maksymowych } 2014 \\
\text { (Maksymowych et al., } \\
\text { 2014) }\end{array}$ & Serum & ELISA & 189 & 99 & & $\begin{array}{l}\text { Con: } 5 \mathrm{IU} / \mathrm{mL} \\
\text { RA: } 53 \mathrm{IU} / \mathrm{mL}\end{array}$ & \\
\hline $\begin{array}{l}\text { Mohamed } 2019 \\
\text { (Mohamed et al., 2019) }\end{array}$ & Serum & ELISA & 60 & 96 & & $\begin{array}{l}\text { Con: } 13.74(11.88) \mathrm{IU} / \mathrm{mL} \\
\text { RA: } 59.07(48.93) \mathrm{IU} / \mathrm{mL}\end{array}$ & \\
\hline $\begin{array}{l}\text { Narayan } 2019 \\
\text { (Narayan et al., 2019) }\end{array}$ & Serum & ELISA & 68 & 152 & $\begin{array}{l}\text { Con: } 0.31 \mathrm{U} / \mathrm{mL} \\
\text { RA: } 295.68 \mathrm{U} / \mathrm{mL}\end{array}$ & $\begin{array}{l}\text { Con: } 11.62 \mathrm{U} / \mathrm{mL} \\
\text { RA: } 30.82 \mathrm{U} / \mathrm{mL}\end{array}$ & \\
\hline $\begin{array}{l}\text { Ozkan } 2012 \\
\text { (Ozkan et al., 2012) }\end{array}$ & Serum & ELISA & 20 & 32 & & $\begin{array}{l}\text { Con: } 1.0 \mathrm{IU} / \mathrm{mL} \\
\text { RA: } 101.0 \mathrm{IU} / \mathrm{mL}\end{array}$ & $\begin{array}{l}\text { Con: } 10.0 \mathrm{mg} / \mathrm{L} \\
\text { RA } 60.0 \mathrm{mg} / \mathrm{L}\end{array}$ \\
\hline $\begin{array}{l}\text { Ramwadhdoebe } 2019 \\
\text { (Ramwadhdoebe } \\
\text { et al., 2019) }\end{array}$ & Serum & ELISA & 8 & 16 & & & $\begin{array}{l}\text { Con: } 0.7 \mathrm{mg} / \mathrm{L} \\
\text { RA: } 4.6 \mathrm{mg} / \mathrm{L}\end{array}$ \\
\hline $\begin{array}{l}\text { Rykova } 2017 \\
\text { (Rykova et al., 2017) }\end{array}$ & Serum & ELISA & 63 & 74 & & $\begin{array}{l}\text { Con: } 6.8 \mathrm{U} / \mathrm{mL} \\
\text { RA: } 16.1 \mathrm{U} / \mathrm{mL}\end{array}$ & $\begin{array}{l}\text { Con: } 2.6 \mathrm{mg} / \mathrm{L} \\
\text { RA: } 21.4 \mathrm{mg} / \mathrm{L}\end{array}$ \\
\hline $\begin{array}{l}\text { Shen } 2014 \\
\text { (Shen et al., 2014) }\end{array}$ & Serum & ELISA & 50 & 88 & & & $\begin{array}{l}\text { Con: } 5.02(3.11) \mathrm{mg} / \mathrm{L} \\
\text { RA: } 41.42(32.83) \mathrm{mg} / \mathrm{L}\end{array}$ \\
\hline $\begin{array}{l}\text { Shrivastava } 2015 \\
\text { (Shrivastava et al., } \\
\text { 2015) }\end{array}$ & Serum & ELISA & 55 & 110 & & & $\begin{array}{l}\text { Con: } 1.18(0.71) \mathrm{mg} / \mathrm{L} \\
\text { RA: } 8.58(5.99) \mathrm{mg} / \mathrm{L}\end{array}$ \\
\hline $\begin{array}{l}\text { Tuncer } 2019 \\
\text { (Tuncer et al., 2019) }\end{array}$ & Serum & ELISA & 29 & 59 & $\begin{array}{l}\text { Con: } 10.1(2.9) \mathrm{IU} / \mathrm{mL} \\
\text { RA: } 407.3(411.3) \mathrm{IU} / \mathrm{mL}\end{array}$ & $\begin{array}{l}\text { Con: } 7.99(3.4) \mathrm{IU} / \mathrm{mL} \\
\text { RA: } 117.2(162.46) \mathrm{IU} / \mathrm{mL}\end{array}$ & \\
\hline $\begin{array}{l}\text { Yan } 2019 \\
\text { (Yan et al., 2019) }\end{array}$ & Serum & ELISA & 60 & 76 & & $\begin{array}{l}\text { Con: } 14.6(6.3) \mathrm{IU} / \mathrm{mL} \\
\text { RA: } 161.5(45.4) \mathrm{IU} / \mathrm{mL}\end{array}$ & $\begin{array}{l}\text { Con: } 5.0(5.1) \mathrm{mg} / \mathrm{L} \\
\text { RA: } 41.2(15.9) \mathrm{mg} / \mathrm{L}\end{array}$ \\
\hline $\begin{array}{l}\text { Yang } 2015 \\
\text { (Yang et al., 2015) }\end{array}$ & Serum & ELISA & 100 & 152 & & $\begin{array}{l}\text { Con: } 12 \mathrm{IU} / \mathrm{mL} \\
\text { RA: } 104 \mathrm{IU} / \mathrm{mL}\end{array}$ & $\begin{array}{l}\text { Con: } 0.87 \mathrm{mg} / \mathrm{L} \\
\text { RA: } 25.41 \mathrm{mg} / \mathrm{L}\end{array}$ \\
\hline
\end{tabular}

"Standard Deviation, ${ }^{* *}$ Control, ${ }^{* * *}$ Rheumatoid arthritis, ${ }^{\dagger}$ Enzyme Linked Immuno Sorbent Assay, ${ }^{~}$ Enti-Cyclic Citrullinated Peptide, "Rheumatoid factor, ${ }^{7 m} \mathrm{C}$-reactive protein 
는 case, Control의 기록, 평가 등이 언급되어 있는지에 대 한 평가이다. 이 분야에서는 최대 4 개 별점을 얻을 수 있 다(Wells et al., 2000).

\section{데이타 추출방법}

모든 추출된 데이타는 조기 류마티스 관절염 환자 대 상의 결과만으로 제한하였으며, ELISA 결과에서 추출하 였다. $\mathrm{RF}$ 의 단위 $\mathrm{IU} / \mathrm{mL}, \mathrm{U} / \mathrm{mL}, \mathrm{CRP}$ 의 단위 $\mathrm{mg} / \mathrm{L}$, Anti$\mathrm{CCP}$ 의 단위 $\mathrm{IU} / \mathrm{mL}, \mathrm{U} / \mathrm{mL}$ 로 통일된 것을 선택하였다. 몇 몇 논문에서는 국제 통일 기준 단위로 표시하지 않은 것 은 모두 제외 하였다(Table 2).

\section{통계 분석방법}

조기 류마티스 관절염 환자를 대상으로 한 총 41개의 논문에서 혈청 마커의 ELISA 결과값을 추출하여 mean difference 값을 토대로 메타분석을 통해 통계량을 합산하 였다. 이질성 검사는 Higgin's $\mathrm{I}^{2}$ 통계량과 Cochrans's Q 검 정, Random effect model을 통해 실시하였고, $\mathrm{I}^{2}$ 이 $50 \%$ 이 상이면 이질적인 것으로 판명하였다. 데이타의 효과크기 는 Forest plot으로 나타내었고, 출판 오류 검사는 Funnel plot을 통하여 살펴보았다. 각 통계량은 신뢰구간 $95 \%$, 통계적 유의수준은 $5 \%$ 로 정하였다. 메타분석 프로그램은 Review Manager (RevMan) 5.4를 이용하였다.

\section{결 과}

류마티스 관절염에서 총 3 가지 진단 혈청 마커들인 $\mathrm{RF}$, $\mathrm{CRP}, \mathrm{Anti-CCP}$ 를 키워드로 각각 또는 중복 포함하는 문헌 수는 291개였고, 제목과 초록 문헌 검색에서 조기 발병이 아닌 문헌과 치료제 관련 문헌, 류마티스 관절염이 아닌 기타 염증 질환과 관련된 문헌은 제외하여 162 개로 추려 졌으며 선택된 논문들을 full-text 문헌으로 조사하여 대조 군과 실험군이 명확하고 정확히 ELISA 결과값(Mean)이 분명한 데이타를 가진 문헌만 선택하여 총 42 개로 메타 분석을 진행하였다(Fig. 1). 또한, 문헌 질평가는 NOS 기 준으로 평가하여 데이타 질 검증 단계를 시행하였다. 총 42 개 문헌에서 각 마커별 대조군과 실험군에서의 혈청 ELISA 값을 추출하여 정리하였다(Table 1). RF는 대체로 ELISA 분석에서 대조군 역할로 RF와 Anti-CCP 또는 RF 와 $\mathrm{CRP}$ 등 데이타가 많았으며 3 가지 마커들을 모두 분석 한 문헌도 존재하였다. 또한 소수이기는 하나 CRP 단독 데이타도 존재하였다. $\mathrm{RF}$ 와 Anti-CCP의 ELISA 값 측정

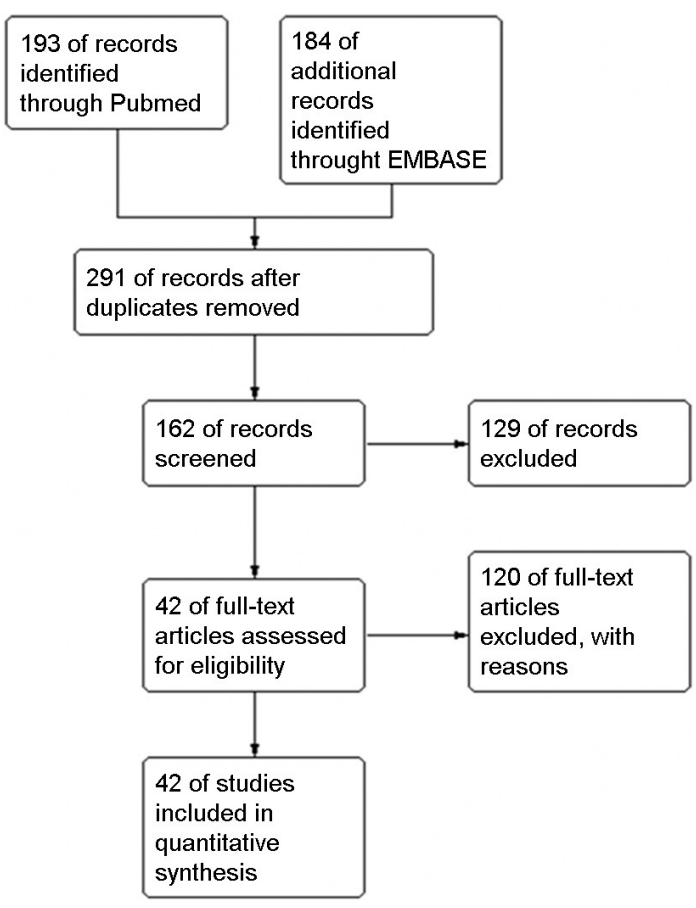

Fig. 1. Flow diagram of study for the systematic review and metaanalysis by PRISMA.

단위는 $\mathrm{U} / \mathrm{mL}$ 과 $\mathrm{IU} / \mathrm{mL}$ 로 통일하여 추출하였으나 그 외 기타 단위는 제외하였다. 그리고 $\mathrm{CRP}$ 측정 단위도 $\mathrm{mg} / \mathrm{L}$ 로 통일하였다.

$\mathrm{RF}$ 의 Forest plot을 보면, 총 32 개 문헌 데이타 분석이다. Mean diffrence 값을 기준으로 다양한 문헌에서 데이타를 추출하였으므로, Random effect model로 분석을 하였다. RF mean difference 값이 가장 큰 것은 Wei 2020에서의 564 이고 $95 \% \mathrm{CI}$ 는 273.13 854.87이며, 가장 작은 것은 Iranshahi 2019로 1이고 95\% CI는 0.58 1.42이다. 총 $\mathrm{RF}$ 의 효과크기는 134.34 이며 95\% CI는 93.62부터 175.05이 다(Fig. 2). 반면에, CRP mean difference 값이 가장 큰 것은 $\mathrm{Kahn}$ 2012에서의 59이고 95\% CI는 58.44 59.56이며, 가장 작은 것은 Giles 2015로 0.2 이고 $95 \% \mathrm{CI}$ 는 $0.0 \sim 0.4$ 이다. 총 $\mathrm{CRP}$ 의 효과크기는 21.42 이며 $95 \% \mathrm{CI}$ 는 14.03 부터 28.82 이다. $\mathrm{CRP}$ 는 총 18 개 문헌 데이타로 분석하였다(Fig. 3). Anti-CCP의 mean difference 값이 가장 큰 것은 Liao 2011 에서의 2172.3 이고 $95 \% \mathrm{CI}$ 는 1260.59 3084.01이며, 가장 작은 것은 Aiman 2020로 28.7이고 95\% CI는 27.74 29.66 이다. 총 Anti-CCP의 효과크기는 270.41 이며 $95 \% \mathrm{CI}$ 는 154.51부터 386.31이다. Anti-CCP는 총 26개 문헌 데이타 로 분석을 하였다(Fig. 4). 본 연구에서의 출판 비뚤림 평 


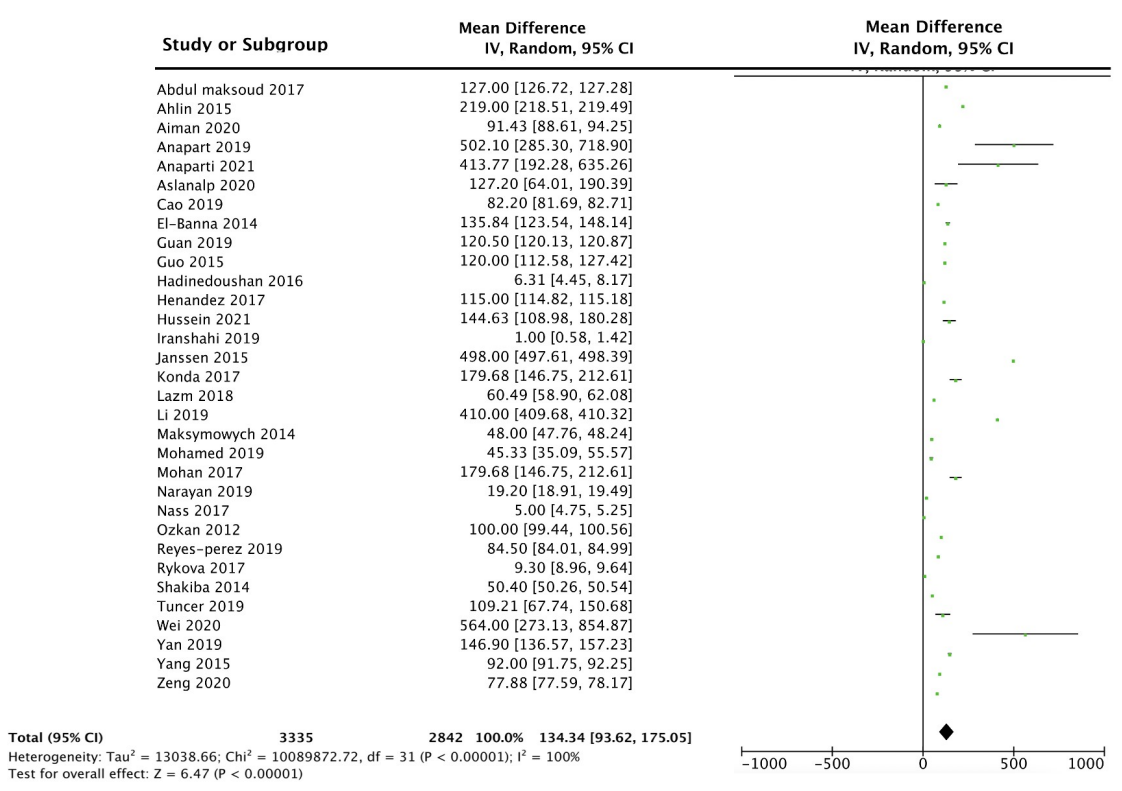

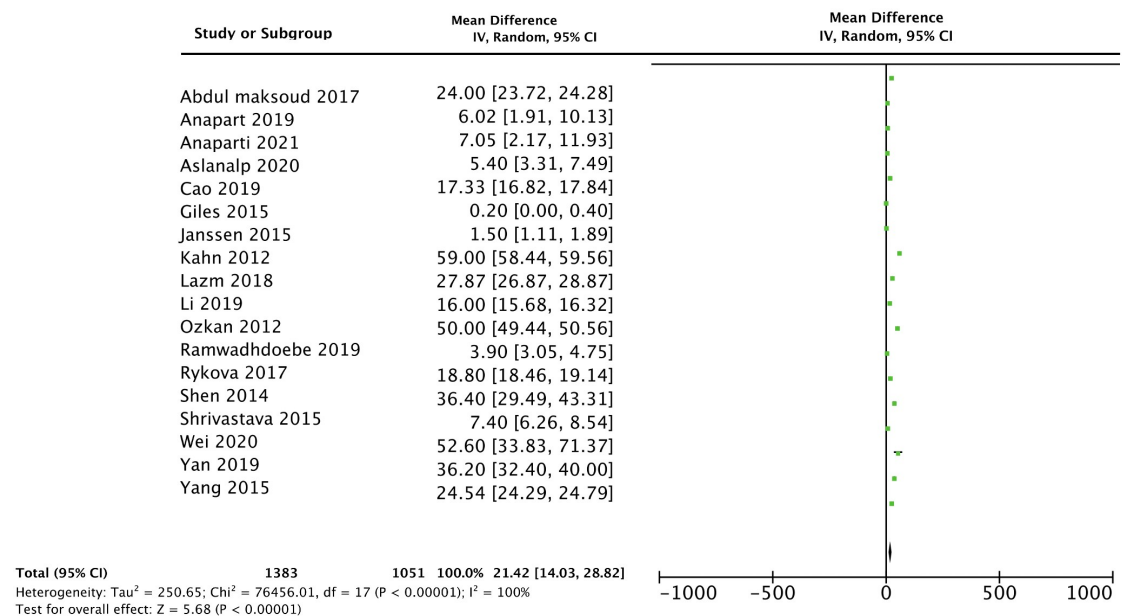

Heterogeneity: Tau $^{2}=250.65 ; \mathrm{Chi}^{2}=76456$.
Test for overall effect: $Z=5.68(\mathrm{P}<0.00001)$

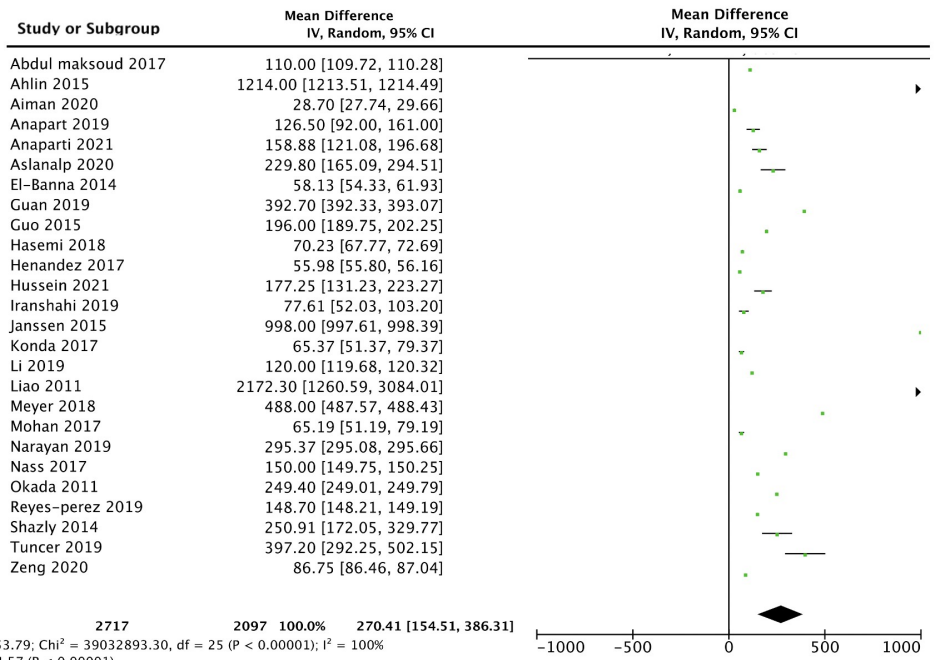

Fig. 3. Forest plot of CRP. Mean differences are indicated by filled squares. The size of the squares indicates the weight of study. The mean difference and $95 \% \mathrm{CI}$ is indicated by diamond. The solid line indicates a range of $95 \%$ CI. CI; Confidence interval.

Fig. 4. Forest plot of Anti-CCP. Mean differences are indicated by filled squares. The size of the squares indicates the weight of study. The mean difference and $95 \% \mathrm{CI}$ is indicated by diamond. The solid line indicates a range of $95 \%$ CI. CI; Confidence interval. 


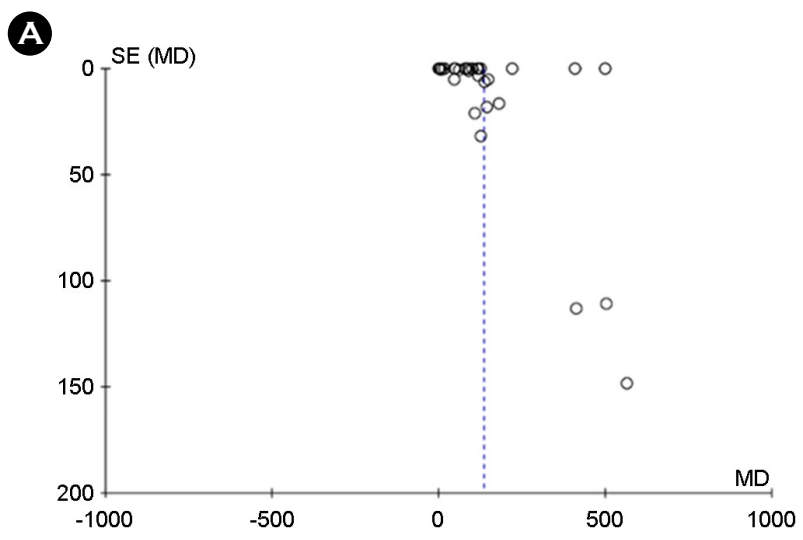

B

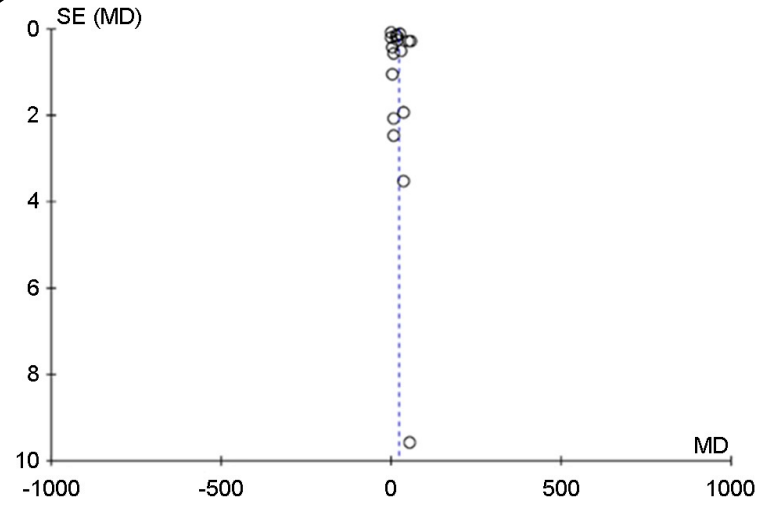

C

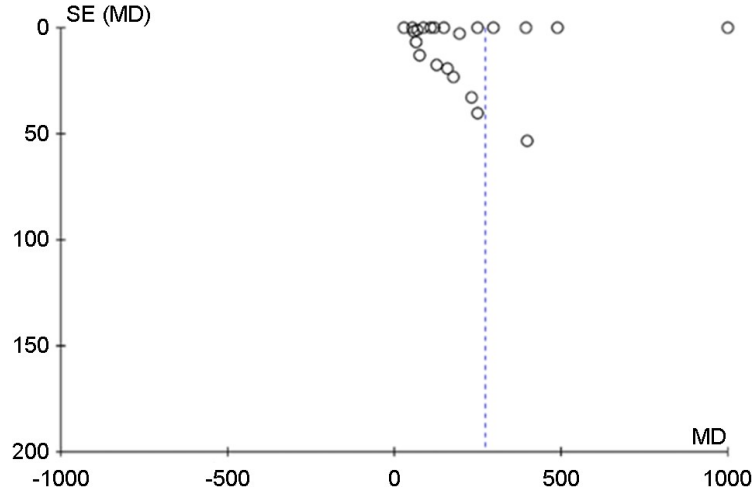

Fig. 5. Funnel plot. (A) RF, (B) CRP, (C) Anti-CCP (SE; standard error, $\mathrm{MD}$; mean difference).

가에서는 RF, CRP, Anti-CCP 마커들의 문헌 데이타 대체로 상단의 꼭대기에 집중됨을 보이므로써, 표본크기가 크다 는 것을 알 수 있다. 이는 표본 연구의 표본수가 커질 수 록 표준오차가 감소하고 정밀도가 증가함을 보여준다. 하 지만, $\mathrm{RF}$ 에서 3 건, $\mathrm{CRP}$ 에서 1건은 중하위 위치에 존재하
므로 표본크기가 작고 비대칭된 점을 보아 출판 비뚤림 이 존재함을 나타낸다(Fig. 5).

\section{고 찰}

본 연구는 조기 류마티스 관절염 환자들의 직접적인 혈청 마커들의 ELISA 데이타를 종합하고, Forest plot을 통 한 RF, CRP, Anti-CCP 총 3가지 혈청 마커에 대한 효과 크기를 비교하였다. 그 결과 Anti-CCP가 가장 컸고, $\mathrm{CRP}$ 가 가장 작게 나타났다. 그렇지만, Anti-CCP에서의 데이타 2 건의 값이 이질성이 커 이를 제외하면 RF와 비슷하거나 클 것으로 생각된다. 그러나 이는 subgroup 분석을 통하 여 원인을 분석할 수 있지만, 5 건 이하라 분석에 큰 의미 는 없을 것으로 사료된다.

따라서, 본 연구 결과의 의미는 류마티스 관절염에서 의 3 가지 혈청 마커 중에서 선행연구에서 보고된 바와 같이 Anti-CCP의 대조군 대비 환자군에서의 유의한 농도 증가에 따른 진단 효과가 크다는 것을 보여준다. 이는 결 국 현재 류마티스 관절염 환자의 진단에 사용되고 있는 혈청 마커들인 RF, CRP와 함께 효과적인 혈청 마커로 사용될 수 있음을 보여준다.

본 연구에서 분석한 문헌 평가는 NOS (case Control) 기준으로 진행하였으며 Funnel plot을 통하여 검증된 문헌 들이 3 가지 혈청 마커에 대한 데이타의 대부분 plot 상 꼭대기 부분에 위치하여 집단 크기와 효과크기가 큰 논 문으로 이루어졌으나 대칭이 아닌 관계로 출판 오류가 존재하였음을 나타내었다. 이는 본 논문 선택의 기준인 영어로 된 논문만을 분석했던 것과 동시에 네가티브한 결과를 출판하지 않는 경우가 전형적인 원인이 이유라 사 료된다.

본 연구 분석에서는 다음과 같은 제한점이 존재한다. 첫째, 수집 문헌을 영어 출판물로, 수집기한을 2011년 1월 부터 2021년 5월 21 일까지로, 출판된 것만 분석하였으며 impact factor 점수 무관하게 문헌을 최대한 수집하여 분 석하였다. 둘째, 실험군 환자는 $2010 \mathrm{ACR}$ 진단기준에 의 해 류마티스 관절염으로 진단된 환자로 제한하였고, 하위 연관 질환은 세부적으로 구분하지 않았다. 셋째, 인종 및 국가별, 나이, 성별 구분을 하지 않아 질환 혈청 마커 농 도에 일부 영향을 줄 수 있는 유전적 및 환경적 요인을 결부시키지 않았다. 넷째, 각 논문 저자들의 실험실 환경 질 정도 관리와 검사 키트 및 장비 등이 통일되지 않아 결과값이 상이하게 나타날 가능성이 있다. 
본 연구 결과에 의하면, 현재 공식적인 RA 조기 진단 마커로 알려진 RF, CRP 보다 Anti-CCP의 진단 효과 및 정확도가 상대적으로 높으나(Reyes-Pérez et al., 2019) RF나 $\mathrm{CRP}$ 와 마찬가지로 RA 뿐만 아닌 다른 염증에서도 검출 이 되듯 하나의 혈청 마커가 아닌 여러 개의 혈청 조합 마커로 진단해야 RA 조기 진단의 특이도를 더욱 높이는 방향이라 생각된다.

결론적으로, Anti-CCP의 메타분석에서의 진단 효과크기 는 $\mathrm{RF}, \mathrm{CRP}$ 보다 크게 분석이 되었으며, 이는 Anti-CCP를 이용한 조기 진단 혈청 마커 개발 및 추가적인 후향적 연구의 효용성이 클 것으로 사료되며, 또한 대표적 혈청 마커로 알려진 RF, CRP 및 Anti-CCP를 조합하여 Panel markers로 사용하는 방안이 매우 효율적일 것으로 기대 된다.

\section{ACKNOWLEDGEMENT}

This research was supported by the Bio \& Medical Technology Development Program of the NRF funded by the Korean government, MSIP (Grant No. 2016M3A9B6904241).

\section{CONFLICT OF INTEREST}

No potential conflict of interest relevant to this article was reported.

\section{REFERENCES}

Abdul-Maksoud RS, Sediq AM, Kattaia A, Elsayed W, Ezzeldin N, Abdel Galil SM, Ibrahem RA. "Serum miR-210 and miR155 expression levels as novel biomarkers for rheumatoid arthritis diagnosis." Br J Biomed Sci. 2017. 74: 209-213. doi: 210.1080/09674845.09672017.01343545. Epub 09672017 Aug 09674847.

Åhlin E, Elshafie AI, Nur MAM, Rönnelid J. "Anti-Citrullinated Peptide Antibodies in Sudanese Patients with Leishmania donovani Infection Exhibit Reactivity not Dependent on Citrullination." Scandinavian Journal of Immunology. 2015. 81: 201-208.

Aiman AQ, Nesrin M, Amal A, Nassar AD. "A new tool for early diagnosis of rheumatoid arthritis using combined biomarkers; synovial MAGE-1 mRNA and serum anti-CCP and RF." Pan Afr Med J. 2020. 36: 270. doi: 10.11604/pamj.12020.11636. 11270.21827. eCollection 12020.

Aletaha D, Neogi T, Silman AJ, Funovits J, Felson DT, Bingham
III CO, Birnbaum NS, Burmester GR, Bykerk VP, Cohen MD. "2010 rheumatoid arthritis classification criteria: an American College of Rheumatology/European League Against Rheumatism collaborative initiative." Arthritis \& Rheumatism. 2010. 62: 2569-2581.

Anaparti V, Meng X, Hemshekhar M, Smolik I, Mookherjee N, El-Gabalawy H. "Circulating levels of free 25(OH)D increase at the onset of rheumatoid arthritis." PLoS One. 2019. 14: e0219109. doi: 0219110.0211371/journal.pone.0219109. eCollection 0212019.

Anaparti V, Smolik I, Meng X, O'Neil L, Jantz MA, Fritzler MJ, El-Gabalawy H. "Expansion of Alternative Autoantibodies Does Not Follow the Evolution of Anti-Citrullinated Protein Antibodies in Preclinical Rheumatoid Arthritis: An Analysis in At-Risk First Degree Relatives." Arthritis and Rheumatology. 2021. 73: 740-749.

Aslanalp Z, Tikiz C, Ulusoy A, Orguc Ş, Bilgi Yedekci A, Ulman C. "The relationship between serum angiogenic factor levels and disease activity in rheumatoid arthritis." Archives of Rheumatology. 2020. 35: 416-425.

Cao G, Chi S, Wang X, Sun J, Zhang Y. "CD4+CXCR5+pd-1+t follicular helper cells play a pivotal role in the development of rheumatoid arthritis." Medical Science Monitor. 2019. 25: 3032-3040.

El Shazly RI, Hussein SA, Raslan HZ, Elgogary AA. "Anti-mutated citrullinated vimentin antibodies in rheumatoid arthritis patients: Relation to disease activity and manifestations." Egyptian Rheumatologist. 2014. 36: 65-70.

El-Banna H, Jiman-Fatani A. "Anti-cyclic citrullinated peptide antibodies and paraoxonase-1 polymorphism in rheumatoid arthritis." BMC Musculoskelet Disord. 2014. 15: 379. doi: 10.1186/1471-2474-1115-1379.

Giles JT, Danielides S, Szklo M, Post WS, Blumenthal RS, Petri M, Schreiner PJ, Budoff M, Detrano R, Bathon JM. "Insulin resistance in rheumatoid arthritis: Disease-related indicators and associations with the presence and progression of subclinical atherosclerosis." Arthritis and Rheumatology. 2015 67: 626-636

Guan SZ, Yang YQ, Bai X, Wang Y, Feng KQ, Zhang HJ, Dong M, Yang HW, Li HQ. "Serum 14-3-3 $\eta$ could improve the diagnostic rate of rheumatoid arthritis and correlates to disease activity." Annals of Clinical and Laboratory Science. 2019. 49: 57-62.

Guo CJ, Lv JH, Niu DS, Ma T, Sun SX, Li LX, Zhao X, Wu L, Jin QH. "Detection of anti-cyclic citrullinated peptide anti- 
bodies in rheumatoid arthritis patients undergoing total knee arthroplasty." International Journal of Clinical and Experimental Medicine. 2015. 8: 4410.

Hadinedoushan H, Noorbakhsh P, Soleymani-Salehabadi H. "Tumor necrosis factor alpha gene polymorphism and association with its serum level in Iranian population with rheumatoid arthritis." Archives of Rheumatology. 2016. 31: 306-313.

Hashemi V, Farrokhi AS, Tanomand A, Babaloo Z, Hojjat-Farsangi M, Anvari E, Tahoori MT, Ezzeddini R, Hosseini A, Gharibi T, Ghalamfarsa G, Jadidi-Niaragh F. "Polymorphism of Foxp3 gene affects the frequency of regulatory $\mathrm{T}$ cells and disease activity in patients with rheumatoid arthritis in Iranian population." Immunol Lett. 2018. 204: 16-22. doi: 10.1016/j.imlet. 2018.1010.1001. Epub 2018 Oct 1014.

Hernández-Bello J, Oregón-Romero E, Vázquez-Villamar M, García-Arellano S, Valle Y, Padilla-Gutiérrez JR, RománFernández IV, Palafox-Sánchez CA, Martínez-Bonilla GE, Muñoz-Valle JF. "Aberrant expression of interleukin-10 in rheumatoid arthritis: Relationship with IL10 haplotypes and autoantibodies." Cytokine. 2017. 95: 88-96. doi: 10.1016/ j.cyto.2017.1002.1022. Epub 2017 Feb 1027.

Hussein MS, El-Barbary AM, Nada DW, Gaber RA, Elkolaly RM, Aboelhawa MA. "Identification of serum interleukin-13 and interleukin-13 receptor subunit expressions: Rheumatoid arthritis-associated interstitial lung disease." International Journal of Rheumatic Diseases. 2021. 24: 591-598.

Iranshahi N, Assar S, Amiri SM, Zafari P, Fekri A, Taghadosi M. "Decreased Gene Expression of Epstein-Barr Virus-Induced Gene 3 (EBI-3) may Contribute to the Pathogenesis of Rheumatoid Arthritis." Immunol Invest. 2019. 48: 367-377. doi: 310.1080/08820139.08822018.01549066. Epub 08822018 Dec 08820134.

Janssen KM, de Smit MJ, Brouwer E, de Kok FA, Kraan J, Altenburg J, Verheul MK, Trouw LA, van Winkelhoff AJ, Vissink A, Westra J. "Rheumatoid arthritis-associated autoantibodies in non-rheumatoid arthritis patients with mucosal inflammation: a case-control study." Arthritis Res Ther. 2015. 17: 174. doi: 110.1186/s13075-13015-10690-13076.

Khan MA, Dixit K, Uddin M, Malik A, Alam K. "Role of peroxynitrite-modified $\mathrm{H} 2 \mathrm{~A}$ histone in the induction and progression of rheumatoid arthritis." Scandinavian Journal of Rheumatology. 2012. 41: 426-433.

Konda Mohan V, Ganesan N, Gopalakrishnan R, Venkatesan V. "HLA-DRB 1 shared epitope alleles in patients with rheumatoid arthritis: relation to autoantibodies and disease severity in a south Indian population." International Journal of Rheumatic Diseases. 2017. 20: 1492-1498.

Lazm AM, Alomashi GB, Jebur MS. "Potential association of proteus mirabilis and strongyloides stercoralis among rheumatoid arthritis patients." Biochemical and Cellular Archives. 2018. 18: $109-114$

Lee CH, Lee KH. "Surgical Treatment for Hand and Wrist Problems in Rheumatoid Arthritis." J Korean Orthop Assoc. 2020. 55: 472-486.

Li W, Liu Y, Zheng X, Gao J, Wang L, Li Y. "Investigation of the potential use of sialic acid as a biomarker for rheumatoid arthritis." Annals of Clinical and Laboratory Science. 2019. 49: 224-231.

Liao J, Ip WS, Cheung KY, Wan WM, Cautherley GWH, Cai X, Lin X, Renneberg R, Chan CPY. "Diagnostic utility of an anti-CCP point-of-care immunotest in Chinese patients with rheumatoid arthritis." Clinica Chimica Acta. 2011. 412: 778781.

Maksymowych WP, Naides SJ, Bykerk V, Siminovitch KA, Van Schaardenburg D, Boers M, Landewé R, Van Der Heijde D, Tak PP, Genovese MC, Weinblatt ME, Keystone EC, Zhukov, OS, Abolhosn RW, Popov JM, Britsemmer K, Van Kuijk AW, Marotta A. "Serum 14-3-3 $\eta$ is a novel marker that complements current serological measurements to enhance detection of patients with rheumatoid arthritis." Journal of Rheumatology. 2014. 41: 2104-2113.

Meyer PWA, Ally MTM, Hodkinson B, Anderson R, Tikly M. "Comparison of the diagnostic potential of three anticitrullinated protein antibodies as adjuncts to rheumatoid factor and $\mathrm{CCP}$ in a cohort of South African rheumatoid arthritis patients." Rheumatol Int. 2018. 38: 993-1001. doi: 1010.1007 /s00296-00018-04036-y. Epub 02018 Apr 00230.

Mimori T. "Clinical significance of anti-CCP antibodies in rheumatoid arthritis." Internal Medicine. 2005. 44: 1122-1126.

Mohamed A, Enein A, Abdelsalam N, Balata M, Abdellatif S, Rizk E, Fathy A. "Utility of anti-carbamylated protein antibodies in the diagnosis of early rheumatoid arthritis." Indian Journal of Rheumatology. 2019. 14: 37-41.

Mun S, Lee J, Lim MK, Lee YR, Ihm C, Lee SH, Kang HG. "Development of a novel diagnostic biomarker set for rheumatoid arthritis using a proteomics approach." BioMed Research International. 2018. 2018.

Mun S, Lee J, Park M, Shin J, Lim MK, Kang HG. "Serum biomarker panel for the diagnosis of rheumatoid arthritis." Arthritis Research \& Therapy. 2021. 23: 1-10. 
Narayan V, Pallinti V, Ganesan N. "A study of serum YKL-40 and its correlation with traditional biomarkers in rheumatoid arthritis patients." Indian Journal of Rheumatology. 2019. 14: 200-205.

Nass FR, Skare TL, Goeldner I, Nisihara R, Messias-Reason IT, Utiyama SRR. "Analysis of four serum biomarkers in rheumatoid arthritis: association with extra articular manifestations in patients and arthralgia in relatives." Rev Bras Reumatol Engl Ed. 2017. 57: 286-293. doi: 210.1016/j.rbre.2016.1003.1001. Epub 2016 Mar 1022

Nell V, Machold KP, Stamm TA, Eberl G, Heinzl H, Uffmann M, Smolen JS, Steiner G. "Autoantibody profiling as early diagnostic and prognostic tool for rheumatoid arthritis." Annals of the Rheumatic Diseases. 2005. 64: 1731-1736.

Okada M, Kobayashi T, Ito S, Yokoyama T, Komatsu Y, Abe A, Murasawa A, Yoshie H. "Antibody responses to periodontopathic bacteria in relation to rheumatoid arthritis in Japanese adults." J Periodontol. 2011. 82: 1433-1441. doi: 1410.1902/ jop.2011.110020. Epub 112011 Feb 110022.

Otterness IG. The value of C-reactive protein measurement in rheumatoid arthritis. Seminars in arthritis and rheumatism, Elsevier, 1994.

Ozkan Y, Mete G, Sepici-Dincel A, Sepici V, Simsek B. "Tryptophan degradation and neopterin levels in treated rheumatoid arthritis patients." Clinical Rheumatology. 2012. 31: 29-34.

Page MJ, McKenzie JE, Bossuyt PM, Boutron I, Hoffmann TC, Mulrow CD, Shamseer L, Tetzlaff JM, Akl EA, Brennan SE. "The PRISMA 2020 statement: an updated guideline for reporting systematic reviews." Bmj. 2021. 372.

Ramwadhdoebe TH, Ramos MI, Maijer KI, van Lienden KP, Maas M, Gerlag DM, Tak PP, Lebre MC, van Baarsen LGM. "Myeloid dendritic cells are enriched in lymph node tissue of early rheumatoid arthritis patients but not in at risk individuals." Cells. 2019. 8.

Reyes-Pérez IV, Sánchez-Hernández PE, Muñoz-Valle JF, MartínezBonilla GE, García-Iglesias T, González-Díaz V, GarcíaArellano S, Cerpa-Cruz S, Polanco-Cruz J, Ramírez-Dueñas MG. "Cytokines (IL-15, IL-21, and IFN- $\gamma$ ) in rheumatoid arthritis: association with positivity to autoantibodies (RF, anti-CCP, anti-MCV, and anti-PADI4) and clinical activity." Clinical Rheumatology. 2019. 38: 3061-3071.

Rykova E, Sizikov A, Roggenbuck D, Antonenko O, Bryzgalov L, Morozkin E, Skvortsova K, Vlassov V, Laktionov P, Kozlov V. "Circulating DNA in rheumatoid arthritis: Pathological changes and association with clinically used serological markers." Arthritis Research and Therapy. 2017. 19.
Shakiba Y, Koopah S, Jamshidi AR, Amirzargar AA, Masoud A, Kiani A, Niknam MH, Nazari B, Nikbin B. "Anti-cyclic citrullinated peptide antibody and rheumatoid factor isotypes in iranian patients with rheumatoid arthritis: Evaluation of clinical value and association with disease activity." Iranian Journal of Allergy, Asthma and Immunology. 2014. 13: 147156.

Shen C, Sun XG, Liu N, Mu Y, Hong CC, Wei W, Zheng F. "Increased serum amyloid $\mathrm{A}$ and its association with autoantibodies, acute phase reactants and disease activity in patients with rheumatoid arthritis." Molecular Medicine Reports. 2014. 11: $1528-1534$

Shen R, Ren X, Jing R, Shen X, Chen J, Ju S, Yang C. "Rheumatoid factor, anti-cyclic citrullinated peptide antibody, C-reactive protein, and erythrocyte sedimentation rate for the clinical diagnosis of rheumatoid arthritis." Laboratory Medicine. 2015. 46: 226-229.

Shrivastava AK, Singh HV, Raizada A, Singh SK, Pandey A, Singh N, Yadav DS, Sharma H. "Inflammatory markers in patients with rheumatoid arthritis." Allergol Immunopathol (Madr). 2015. 43: 81-87. doi: 10.1016/j.aller.2013.1011.1003. Epub 2014 Mar 1020.

Tuncer T, Kaya A, Gulkesen A, Kal GA, Kaman D, Akgol G. "Matrix metalloproteinase-3 levels in relation to disease activity and radiological progression in rheumatoid arthritis." Advances in Clinical and Experimental Medicine. 2019. 28: 665-670

Wei Y, Peng L, Li Y, Zhang N, Shang K, Duan L, Zhong J, Chen J. "Higher Serum CCN3 Is Associated with Disease Activity and Inflammatory Markers in Rheumatoid Arthritis." Journal of Immunology Research. 2020. 2020.

Wells GA, Shea B, O'Connell D, Peterson J, Welch V, Losos M, Tugwell P. The Newcastle-Ottawa Scale (NOS) for assessing the quality of nonrandomised studies in meta-analyses, Oxford, 2000.

Yan S, Wang P, Wang J, Yang J, Lu H, Jin C, Cheng M, Xu D. "Long Non-coding RNA HIX003209 Promotes Inflammation by Sponging miR-6089 via TLR4/NF-kB Signaling Pathway in Rheumatoid Arthritis." Frontiers in Immunology. 2019. 10

Yang L, Zhang J, Tao J, Lu T. "Elevated serum levels of Interleukin37 are associated with inflammatory cytokines and disease activity in rheumatoid arthritis." APMIS. 2015. 123: 10251031

Zeng T, Tan L, Wu Y, Yu J. "14-3-3ๆ protein in rheumatoid arthritis: Promising diagnostic marker and independent risk factor for osteoporosis." Lab Medicine. 2020. 51: 529-539. 
https://doi.org/10.15616/BSL.2021.27.4.298

Cite this article as: Woo MS, Mun S, Kang HG. MetaAnalysis of Effect in Serum Bio-Markers for Early Diagnosis: Rheumatoid Arthritis. Biomedical Science Letters. 2021. 27: 298-309. 